\title{
O Caso República e a retórica nos discursos políticos: Um estudo descritivo
}

\author{
Virgílio Amaral ${ }^{*}$ S Susana Pereira** \\ " Centro de Estudos Sociais, Universidade de Coimbra; ${ }^{* *}$ ISPA - Instituto Universitário
}

\begin{abstract}
Aos capitães-de-abril
Este estudo teve como objectivo perceber, através de práticas discursivas veiculadas na imprensa oficial de dois grupos políticos - Partido Socialista e Partido Comunista Português -, a forma como estes dois partidos políticos construíram o significado de um incidente crítico que os opôs - o conflito no jornal "República" - no contexto revolucionário do pós 25 de Abril. Enquadrado nos pressupostos de "uma proposta pós moderna" de análise retórica de discurso (Billig, 1991, 2012), bem como das propostas da Análise Crítica de Discurso de Van Dijk (2006), em particular sobre as dicotomias argumentativas utilizadas pelas formações políticas em confronto, procedeu-se à reconstrução quer das polaridades ideológicas utilizadas pelos dois partidos, quer à interpretação dos momentos em que os discursos políticos se veiculam como maioritários vs. minoritários, e, desse modo, apresentar uma análise daqueles discursos com base no pressuposto de Billig $(1991,2012)$ de que a defesa de uma determinada posição só é entendível como oposição (explícita ou implicitamente) a uma posição contrária. No discurso socialista o caso "República" é construído como argumento retórico que invoca aquilo a que se opõe - o "totalitarismo" da atuação do PCP - promovendo uma mobilização que, num contexto de legitimidade eleitoral (Eleições para a Assembleia Constituinte, ganhas pelo Partido Socialista), convoca os portugueses à luta pela liberdade de expressão, através de uma generalização retórica do incidente. No discurso comunista, a retórica do argumento conspirativo ("aliança" do PS a forças que se opunham ao processo revolucionário) associado a uma bipolarização da realidade (Reacção vs. Revolução) em torno do caso, seve o propósito de legitimar a actuação revolucionária do Partido no âmbito do pós 25 de Abril (nomeadamente, tendo em conta a "aliança Povo - MFA", recorrentemente evocada). A análise dos discursos, também tendo em conta os mecanismos retóricos identificados por Potter (1996) e Castro (2002), permitiu proceder à reconstrução do significado do conflito subjacente aos argumentários apresentados pelos dois grupos políticos em confronto. Em causa estão diferenças ideológicas e posições sobre a condução política futura do país, em torno de duas legitimidades: revolucionária vs. eleitoral
\end{abstract}

Palavras-chave: 25 de Abril de 1974, Análise de discurso, Retórica, Política.

\section{INTRODUÇÃO}

No presente trabalho procura-se abordar os discursos retóricos em torno de um dos incidentes críticos no contexto revolucionário do pós 25 de Abril - o "Caso República" - veiculados por duas formações políticas, o Partido Socialista e o Partido Comunista Português.

Trabalho financiado pela Fundação para a Ciência e Tecnologia, bolsa de Investigação SFRH/BPD/79663/2011. A correspondência relativa a este artigo deverá ser enviada para: Virgílio Amaral, Centro de Estudos Sociais da Universidade de Coimbra, Colégio de S. Jerónimo, Apartado 3087, 3000-995, Coimbra. E-mail: vamaral@ces.uc.pt 
Através da retórica política, ambos os partidos procuraram impor determinadas "significações" (Bordieu, 1989) em torno de polaridades ideológicas (Van Dijk, 2006), decorrentes de duas visões sobre a natureza da legitimidade política: uma "legitimidade eleitoral" reivindicada pelo PS, a partir das eleições para a Assembleia Constituinte, e uma "legitimidade revolucionária", assente no pacto MFA - Partidos, reivindicada pelo PCP. Através da análise da retórica política utilizada pelas duas formações partidárias em questão, procura-se compreender alguns processos de construção social da realidade política na época.

\section{Enquadramento histórico, social e político do "Caso República"}

As características contextuais do período revolucionário do pós 25 de Abril são importantes para compreensão do caso em análise, e da retórica política em torno do mesmo, assim como da construção social da realidade política da época (Berger e Luckman, 1966/1973), dado que se trata de um período da história de Portugal no qual "se remeteram muitos dos comportamentos individuais e coletivos a uma legitimidade excepcional, fora do quadro normativo - legitimidade revolucionária" (Babo-Lança, 2006, p. 135).

O regime ditatorial precedente teve implicações não só obviamente políticas, mas também sociais e económicas. $\mathrm{O}$ fascismo assentou numa ideologia e estrutura capitalista monopolista, que implicou a exploração de grande parte da classe operária e trabalhadora (Rosas, 1994). A revolução e o fím do regime simbolizaram, à esquerda, o fim da referida opressão. Em parte, devido a este facto, e como refere Varela (2011, p. 125), termos como “'socialismo', 'sociedade sem classes', 'revolução', 'democracia' faziam parte do léxico propagandístico de todos os dirigentes políticos portugueses, do PPD ao PS, do PCP à extrema-esquerda”, léxico que perdura ainda hoje, por exemplo, na designação do PPD-PSD: "Portugal é o único país na Europa que tem um partido liberal que se chama social-democrata" (Varela, 2011, p. 125).

Como refere também aquela autora, e numa perspectiva histórica, "os discursos, os programas políticos, os documentos são relevantes pelo que dizem, também pelo que não dizem”, a que acrescentaremos a estas considerações que, para a compreensão histórica do período revolucionário do pós 25 de Abril, será também necessário entender o contexto e estratégias argumentativas em que o que é dito ganha um significado preciso, com funções não só retóricas, mas com implicações históricas, como sejam as dificuldades de entendimento entre as formações políticas no espectro da esquerda portuguesa.

É certo que o contexto revolucionário do pós 25 de Abril, nomeadamente o Período Revolucionário em Curso (PREC) (assim, então designado, o período compreendido entre a tentativa de golpe de estado a 11 de Março até aos acontecimentos 25 de Novembro de 1975) foi um conturbado período, seja de agitação popular, como de instabilidade governativa, relativa a sucessivos governos provisórios de base pluralista, com representantes de várias forças políticas, cujos conflitos eram mediados pelo MFA, entretanto institucionalizado com a criação do Conselho da Revolução, do qual emanaram, aliás, políticas de atuação estratégica para o país (Medeiros Ferreira, 1994).

Tais conflitos, entre, por um lado, o PS e forças conotadas com o mesmo ou à sua direita, e, por outro, o PCP e forças conotadas com o mesmo ou à sua esquerda revelaram-se em tantos outros Incidentes Críticos da época (Medeiros Ferreira, 1994).

Acontecimento histórico de primordial importância foi o golpe de extrema-direita a 11 de Março de 1975. Para além das repercussões políticas (como a institucionalização do MFA) ou políticoeconómicas (como as nacionalizações na Banca e nos Seguros), determinará um posicionamento argumentativo próprio do PCP, relacionado com as suas prioridades políticas, e o seu entendimento de uma nova fase da revolução (cf. Brito, 2010, p. 139).

Não serão apenas termos como "Revolução" ou "Socialismo" que adquirirão sentidos diversos nos argumentários dos Partidos em questão, mas o próprio termo "Democracia”. Se para o PS, a 
partir das eleições de 25 de Abril de 1975, a "Democracia" corresponderia a uma "democracia pluralista" de base parlamentar" (Reis, 2005), para o PCP essa Democracia seria "uma democracia burguesa que não serve a Portugal” (Cunhal, citado por Varela, 2011, p. 203).

É pois neste contexto, quer histórico, quer do ponto de vista do argumentário político, que se pode compreender a Retórica política em torno de um dos Incidentes Críticos que opôs, de novo, o PS ao PCP, no caso a propósito do controlo dos meios de comunicação social, e que serviu de pretexto ao PS para a sua saída do IV Governo provisório (cf, Soares in Avillez, 1996, p. 438).

\section{O Caso República: Duas versões em confronto}

Durante o salazarismo o jornal "República" simbolizava (juntamente com o "Diário de Lisboa"), na imprensa legal, a resistência possível ao regime. Segundo Mesquita (2005) o jornal "chegou ao 25 de Abril (...) com o prestígio de ter sido o único diário português que se assumia, explicitamente, como órgão da oposição democrática" (parágrafo 14).

De acordo com Soares (Avillez, 1996: 437) o "República" era "uma voz republicana e liberal, aberta a todas as correntes e matizes da oposição, incluindo os próprios comunistas", sendo propriedade de acionistas socialistas. De acordo com o próprio Soares (Avillez, 1996), após o 25 de Abril de 1974, os novos estatutos do jornal vinculavam-no "à sua vocação socialista, pluralista e independente" (Avillez, 1996, p. 437).

Mesquita (2005), ao proceder a um enquadramento do Caso República, e no contexto mais amplo dos confrontos entre PS e PCP, refere que a partir de Junho de 1974:

“o mal-estar instalou-se na redacção, ainda em surdina, entre os sectores afectos ao PS e ao PCP. Os jornalistas e outros trabalhadores afectos ao PCP queixavam-se que o PS pretendia fazer prevalecer uma orientação partidária, enquanto os socialistas alegavam defender um órgão autónomo mas de tendência socialista democrática".

Para Mesquita (2005) “os comunistas (...) procuravam impor a sua concepção censória de unidade antifascista, o que, naturalmente, colidia com qualquer crítica (...) ao socialismo de modelo soviético" (Mesquita, 2005, parágrafo 15). Segundo Soares (in Avillez 1996), na sequência dos acontecimentos do $1^{\circ}$ de Maio de 1975 (sobre os mesmos ver: Medeiros Ferreira, 1994; Soares, in Avillez, 1996) deu-se o "último assalto comunista" (Avillez, 1996, p. 437) ao controlo dos meios de comunicação social (segundo Avillez, 1996, aqueles "dominavam já o 'Século', o 'Diário de Notícias' e o 'Diário Popular"” e o 'República' seria "uma bandeira de resistência socialista" ao PCP no âmbito da comunicação social (Avillez, 1996, p. 437). Nas palavras de Soares (1996, in Avillez, 1996, p. 437):
"Nas horas que se seguiram aos acontecimentos do $1^{\circ}$ de Maio, deu-se o último assalto comunista: os tipógrafos não só impediram os redactores socialistas de estamparem a sua versão desses mesmos acontecimentos, como publicaram uma edição em cujo cabeçalho figurava Álvaro Belo Marques, homem muito conotado com os sectores comunistas".

De acordo com Mesquita (2005), a deterioração das relações dentro do jornal culminaram, a 19 de Maio de 1975, com a invasão do mesmo por um grupo de trabalhadores que pretendiam alterar a orientação do jornal e pedir a demissão da direção e redatores, que implicou o sequestro do diretor do jornal, Raul Rego, e de jornalistas afetos ao PS.

O "Caso República", aqui descrito muito sucintamente, para além de servir de argumento ao PS para o abandono do IV Governo Provisório, teria uma ampla cobertura internacional, e ainda de acordo com Soares (Avillez, 1996, p. 441) " foi a primeira grande 'campainha de alarme' tocada no exterior, anunciando que a democracia portuguesa estava em perigo". 
Às considerações de Mesquita (2005) ou Soares (Avillez, 1996), contrapõem-se as de Dil e Pina (1975) que se referem ao conflito como uma estratégia socialista: "conseguiu a cúpula do PS escamotear as origens da crise, no interior do jornal, dirigindo contra outros aquilo que era acusada: o de ter transformado o 'República', através de militantes na redacção, direcção e administração, num seu órgão oficial” (Dil \& Pina, 1975: 25).

Um jornalista do "Expresso" (citado em "Portugal Socialista" de 23/5/1975: 15) descreve o enquadramento geral que foi dado na opinião pública:

"Há duas teses em conflito. A da posição da Redacção e da Direcção que, em nome da independência do jornal e da liberdade de imprensa, pretende que continue o mesmo corpo redactorial e a mesma direç̧ão. Outra tese é a de outros trabalhadores, que também em nome da liberdade e independência não desejariam que a direcção continuasse".

\section{CONSIDERAÇÕES TEÓRICO-METODOLÓGICAS SOBRE A ANÁLISE DE DISCURSO RETÓRICO}

Perelman (1997), filósofo responsável pelo movimento dos estudos da Nova Retórica, reivindica as bases de tal abordagem em Aristóteles. Aristóteles, no seu Organon, distingue dois tipos de raciocínios: o raciocínio analítico, que visa relacionar a verdade das premissas com a das conclusões; e o raciocínio dialéctico, assente em premissas que são constituídas por opiniões geralmente aceites, para fazerem aceitar outras teses que podem ser controversas, visando a persuasão.

É ao raciocínio dialético que o discurso retórico está associado. Assim, por exemplo, o domínio da argumentação política, filosófica, literária e inclusive jurídica "é do verosímil, do plausível, do provável, na medida em que (...) escapa às certezas do calculo" (Perelman \& Olbrechts-Tyteca, 2006, p. 9).

Adotamos neste trabalho as perspetivas discursivas sobre a retórica em Psicologia Social, seja da Psicologia Retórica de Billig (1991, 2012), da Análise Crítica de Discurso de Van Dijk (2006), e da análise dos mecanismos de construção de argumentação (Castro, 2002; Potter, 1996).

Também se tem em conta o modelo de análise proposto por Potter (1996), retomado por Castro (2002), em alguns aspetos focado por Van Dijk (2006), que permite a identificação de mecanismos retóricos inerentes ao discurso persuasivo: a extremização de argumentos visando predispor uma audiência a uma ação, ou a sua inversa, a minimização; a descrição de argumentos com recurso a dados factuais; a argumentação por inoculação (pretender mostrar à audiência que se não há interesse do sujeito no argumento que apresenta); o mecanismo de distanciamento (assumir neutralidade e pretender que não se vai provar nada); a apresentação de credenciais na argumentação (recurso a categorias de sujeitos com conhecimentos particulares sobre o assunto, de forma a tornar a mensagem credível).

\section{MÉTODO}

Período em análise: Maio a Julho de 1975.

Corpus de Análise: Imprensa escrita dos órgãos oficiais do PS (Portugal Socialista) e do PCP (Avante)

Foram selecionadas 26 notícias, 13 de cada jornal, considerando-se como critérios de seleção os seguintes: serem artigos de opinião sobre o caso; corresponderem a discursos políticos sobre a 
situação no país e/ou sobre o caso; ou corresponderem a notícias com conteúdo relevante para perceber o enquadramento histórico, social e político em que ocorre o "Caso República".

\section{Procedimento}

- Identificação e contraste entre argumentos apresentados por cada uma das forças políticas.

- Reconstrução dos discursos, através da interligação entre os argumentos (conteúdos) e respetivas funções retóricas.

- Identificação de mecanismos retóricos utilizados, com base na sistematização de Potter (1996) e Castro (2002).

\section{RESULTADOS}

De seguida elencam-se todas as notícias selecionadas, seguidas de uma análise individual a cada uma delas, procurando-se nesta análise identificar os argumentos e recursos retóricos usados nos discursos.

\section{Avante! (13 noticias analisadas)}

\section{2/5/75 - A Revolução, as Eleições, os Partidos e a Economia}

Neste artigo é feita uma análise política ao contexto pós eleitoral, que antecede o acontecimento em análise. Nesse contexto são veiculados o que se entende por um conjunto de argumentos e formatos retóricos, com vista a fazer prevalecer a imagem de força revolucionária, face a resultados eleitorais pouco favoráveis. A legitimidade eleitoral conquistada pelo PS é posta em confronto com alguns argumentos, nomeadamente:

1) O Argumento da Conspiração (a reação e o eleitoralismo): “A reacção tem ainda muita força. A conspiração continua. Persistem as ameaças às liberdades." Esta é forma como Cunhal descreve o período em que decorreram as eleições cujos resultados não lhe foram favoráveis. Recorre à técnica retórica de inoculação para suportar uma aparente mudança de atitude. O acto eleitoral é legítimo num regime democrático em que não haja "perigo de golpes reaccionários", mas para Cunhal essa não é a vivência do país e portanto as eleições não podem ser consideradas "as eleições livres ansiadas pelo povo português". Cunhal expressa a sua intenção de que um dia Portugal venha a conhecer as eleições livres e que estas venham a "constituir eixo fundamental da vida política e uma fonte determinante de decisões".

2) Pluralismo: Novamente aqui a construção do discurso em torno do argumento reação parece servir um outro propósito. Deslegitimar um argumento consensual - o pluralismo defendida por todos os atores na esfera política, sem o pôr em causa. O discurso constrói a sua argumentação invocando a atuação reacionária que alguns quadrantes da cena política, e em coligação têm demonstrado, uma alusão ao PS que faz "coro com a reacção e com tudo quanto há de politicamente desclassificado na campanha anticomunista". O seguinte extrato é ilustrativo da argumentação utilizada:

“somos pois contrários a essa condenação global do papel dos partidos que aqui e acolá se começa a esboçar. Mas essas tendências ganharão rapidamente terreno, se a acção dos 
partidos não se inserir no processo revolucionário (...) o sistema de coligação de partidos e MFA poderá tornar-se inviável e outras soluções terão de ser encontradas para assegurar a vitória da revolução e a marcha para o socialismo".

A construção do discurso parece promover assim uma alteração na sua atitude (explícita) a favor do pluralismo. Parece implícito que só é defendida enquanto mantém a sua função de símbolo de democracia popular e nacional, ao serviço do processo revolucionário. A construção é feita de forma dialética e bipolarizada: se deixar de servir os "interesses revolucionários" significa que a democracia está a ser posta em causa e portanto deixa de ser símbolo desta para passar a ser sinónimo de voz da reaç̧ão e portanto "outras soluções terão de ser encontradas".

A sua defesa era tática - fenómeno que pode ser interpretado à luz do que Billig $(1991,2012)$ define como "taking the side of the other". Ao assumir que "o sistema de coligação partidos e MFA poderá tornar-se inviável e outras soluções terão de ser encontradas" está-se a prevenir uma posição futura. O argumento que hoje é defendido amanhã pode deixar de o ser, em nome do processo revolucionário.

\section{2/5/75 O Caso do Jornal «República»}

Primeira notícia veiculada pelo Jornal Avante sobre o caso República. Aparece na terceira página do jornal, sem grande destaque, no que sugere ser um recurso retórico de minimização do acontecimento, em contraposição ao empolamento político que o PS deu ao caso. A notícia descreve muito sucintamente os factos ocorridos estendendo-se essencialmente numa contra argumentação à postura pública do PS sobre o caso: "com vista a garantirem a tradicional independência do jornal, os trabalhadores da República exigiram a demissão do director e de outros elementos responsáveis."

O "República", reconhecido como independente pela luta antifascista vê agora a sua independência ameaçada por uma orientação política. Através do argumento retórico "tradicional independência ameaçada" o PCP procura legitimar a atuação dos trabalhadores perante a opinião pública. Como é que o faz? Por um lado constrói a sua argumentação enaltecendo a imagem destes trabalhadores, "pilar das liberdades em Portugal", que reivindicam a independência do jornal, pois contribuíram para que "grande parte dos jornais, a Rádio e a TV fossem retiradas da influência dos monopólios e colocadas decididamente ao serviço do processo revolucionário e da aliança PovoMFA." Por outro lado invoca a argumentação do PS sobre a liberdade ameaçada e confronta esse argumento com o facto de o jornal ser "gerido por membros do partido socialista", como "é do conhecimento geral":

“(o) PS refere-se a si como defensor da liberdade... mas se eles fazem parte da direcção do jornal e consideram que este é o único independente... os restantes jornais não partidários, com profissionais que defenderam os órgãos de informação em que trabalham contra o domínio monopolista e deles têm feito bastiões da revolução portuguesa como se classificam?"

\section{8/5/75 - O Povo está com o MFA o MFA está com o Povo}

A presente notícia contém uma descrição crítica da mobilização organizada pelo PS após a invasão do Jornal República. Evoca a atuação do PS, descrita como anticomunista e reacionária, para reforço do argumento conspirativo.

O exemplo do caso República surge para reforço do argumento conspirativo, juntamente com a alusão a interesses internacionais cuja atuação sugere uma "estratégia coordenada contra a jovem democracia portuguesa": 
“Infelizmente em Portugal é o PS, dito de esquerda, que persiste em manter erguido o pendão do anticomunismo. A forma como foi adulterado e empolado o problema do jornal República, os ataques abertos ao MFA e ao processo revolucionário português, (...) a rapidez com que foi orquestrada a campanha contra Portugal democrático, por círculos da socialdemocracia europeia e estranhamente por responsáveis da política americana em defesa da "liberdade ameaçada" em Portugal, são tudo factos que sugerem uma estratégia coordenada contra a jovem democracia portuguesa”.

A descrição feita, em tom de crítica pelo PCP, da atuação do PS é, aqui, extrapolada para o caso República:

"Entulhar os cérebros de propaganda tendenciosa para mascarar objectivos políticos inconfessáveis; (...) utilizando fórmulas ridículas para transformar a mentira torpe na verdade pura (...) dirigentes políticos e ministros do governo provisório a dançarem e cantarem sambinhas insultuosos contra ministros do mesmíssimo governo (...) alaridos do anticomunismo delirante (...) o PCP, como partido, nada pesou na decisão dos trabalhadores da 'República' de sanearem o director e alguns redactores do jornal'.

Há um enaltecimento da aliança povo-MFA, a qual aparece taticamente associada ao processo revolucionário enquanto defensora dos interesses do povo e contrária aos interesses anticomunistas:

"A feroz campanha anticomunista vai mais longe - procura atingir o próprio processo revolucionário através do enfraquecimento, primeiro, e da destruição, depois, do principal pilar e força determinante da revolução portuguesa - a aliança povo-MFA (...) o PCP não pretende implantar a ditadura de um partido único e defende o pluralismo partidário não só hoje mas também para amanhã, em estreita aliança com o MFA.”

\section{8/5/75 - Álvaro Cunhal no Couço}

Novo reforço no seu discurso das divergências PCP-PS. Utiliza um discurso dialético ao caracterizar a realidade política portuguesa através da existência de dois movimentos que se contrapõem: força revolucionária, representada pela aliança entre os dois componentes essenciais ao processo revolucionário (o "movimento popular" e o MFA) e as forças reacionárias, que com "tentativas desesperadas", ambicionam "dividir e quebrar" essa aliança: "ou continua a coligação com socialistas e outros portugueses, mas esses partidos vão para diante com o MFA e com outras forças revolucionárias para o socialismo, ou os socialistas insistem em cortar o passo à revolução". Há, pois, um posicionamento estratégico do PS do lado das forças reacionárias, que devem ser combatidas. O discurso do PCP constrói-se como aliado do Povo, defensor dos seus interesses, traduzindo-se essa aliança no argumento retórico da referida aliança "Povo-MFA".

Referindo-se às divergências entre PCP e PS, estas acontecem porque "o PS não quer que a revolução vá para a frente, porque o PS não quer o Socialismo em Portugal. (...) Praticam um socialismo "vigarista"".

No discurso de Cunhal há um incitamento à unidade popular em defesa da revolução e contra a reação. É um discurso com características propagandistas, com uma comunicação dicotomizada em "forças da revolução vs. forças da reação": "Pela nossa parte, tudo faremos para evitar uma crise grave (...) o mal está em que os outros não queiram". Fazem um discurso repetitivo com foco nos comportamentos, de incitamento à unidade popular (entendida como uma componente da aliança com o MFA) contra as forças reacionárias:

“a revolução portuguesa não pode ser sacrificada, é necessário que todo o povo se una em defesa da revolução e das suas conquistas, e que as forças democráticas e populares, junto 
com as Forças Armadas, garantam o prosseguimento da revolução portuguesa em direcção ao socialismo".

\section{8/05/75 - Nota do PCP sobre a Situação Política}

Neste artigo o caso República é usado como argumento para reforçar a teoria da conspiração e justificar uma possível reversão de intencionalidade (inoculação) face à coligação. O PCP posiciona-se como apologista da coligação com o PS, mas em simultâneo refere que os comportamentos "anti-comunistas" demonstrados por aquele partido põem em causa a coligação e, em consequência o processo revolucionário.

A invocação de um PS divisionista parece reforçar por um lado a imagem de um PC conciliador em nome da unidade do povo, pela qual "tem lutado infatigavelmente" e por outro lado legitimao na sua tomada de posição face à coligação: "as posições e atividades do PS podem porém conduzir à impossibilidade do Governo de coligação e de todo o atual sistema de Poder".

\section{5/6/75 - Dois processos inconciliáveis}

Os dois processos inconciliáveis correspondem ao "Eleitoralismo" (a que se terá assistido nas eleições para a Assembleia Constituinte) e o processo revolucionário - ocorre uma construção destes dois argumentos como inconciliáveis, num contexto em que PCP precisa persuadir o povo português a manifestar-se publicamente a seu favor, face a um resultado eleitoral que o remete para força política minoritária - em contraponto com o PS cujos resultados o elevam a força representativa maioritária do povo português. O caso República serve como argumento de reforço da descredibilização dos resultados eleitorais ao contribuir para reforço do argumento conspirativo que serve, como se pode verificar pelo seguinte extrato da notícia:

"O carácter inconciliável do eleitoralismo e do processo revolucionário salta à vista do observador minimamente informado. O ‘eleitoralismo’ é (...) um apêndice da demagogia da classe burguesa, do seu falso democratismo (...) política que procura retirar do resultado de um acto eleitoral recheado de factores muito controversos, ainda mal analisado na sua estrutura interna, a força para impor soluções à problemática nacional concreta e, em última análise, para impôr todo um sistema de sociedade que não correspondem nem à opção de facto expressa pelas massas populares nas eleições do 25 de Abril, nem à verdadeira correlação de forças sociais e políticas do País."

\section{2/6/75 - Dinamizar a iniciativa das massas. Derrotar a reacção}

Nesta notícia faz-se uma descrição do que se considera serem ofensivas contra o processo revolucionário - ocorrendo, de novo, um reforço do argumento da conspiração.

A construção do discurso convoca a atuação dita reacionária para dar força e legitimar a representação de um perigo eminente (conspirativo) que deve ser travado com a mobilização das massas face ao caminho "irreversível de destruição do capitalismo":

"milhares de trabalhadores deram uma resposta revolucionária às manobras da reacção. A linha divisória entre as forças que estão decididas a bater-se pela construção de uma sociedade a caminho do socialismo e aquelas que intensificam esforços para tentar salvar o capitalismo moribundo tornou-se mais nítida".

São referidas Ofensivas Internas e Externas à Revolução:

1) Ofensiva Interna:

"há indícios de que preparam uma ofensiva em múltiplas frentes. Forças heterogéneas com métodos e linguagens diferentes. Umas abertamente reaccionárias, outras sob vestes 
democráticas conseguem enganar sectores pouco esclarecidos da população e até confundir trabalhadores iludidos pelas suas promessas de fidelidade à Revolução e ao socialismo."

\section{2) Ofensiva externa:}

“As pressões externas (...) visam dar alento às combalidas forças do capitalismo português e a intimidar e fazer recuar aquelas que as combatem. As notas dominantes dessa campanha são um anticomunismo virulento e a solidariedade calorosa a todas as iniciativas divisionistas do Partido Socialista."

Perante estas duas ofensivas "a revolução Portuguesa tem de encontrar as respostas adequadas". E essas respostas cabem, no momento, ao movimento popular de massas e ao MFA:

"Desde o 25 de Abril que o processo tem avançado através de sucessivas derrotas infligidas à reacção. Mas foi sempre ela quem atacou primeiro, quem escolheu o momento e a forma do confronto. Hoje estão criadas as condições para que a iniciativa mude de campo. Não se deve oferecer às forças que conspiram contra a Revolução a oportunidade de desencadear em grande estilo a ofensiva que preparam. Essa ofensiva pode ser morta no berço, pode ser impedida mediante a acção consequente e revolucionária das duas componentes do processo (...) O MFA tem cumprido o seu papel na dinamização e reforço da aliança. Mas o movimento popular das massas, no contexto da luta de classes em curso, tem um amplo campo de acção a ocupar. ... é preciso que a mobilização popular se aprofunde (...) que se estruture eficazmente em moldes revolucionários."

\section{2/6/75 - Álvaro Cunhal em Montemor}

O PCP utiliza o seu passado de luta antifascista como argumento retórico (mecanismo de apresentação de credenciais). Em defesa de uma liberdade, que o partido entende ser acusado de querer usurpar, o passado credibiliza-o enquanto defensor máximo desse "direito democrático fundamental". O passado é invocado com a função de credibilizar o PCP enquanto defensor das liberdades do povo português:

“Hoje em Portugal há muita gente que gostaria de fazer esquecer o passado... o Povo não esquece nem esquecerá o que significou quase meio século de fascismo. Não esquece porque mantendo bem viva essa lembrança, mais força e mais determinação o inspirará na luta para que esse passado não volte. Tem particular significado lembrarmos o tempo do fascismo porque a luta pela liberdade não terminou. No tempo do fascismo lutava-se por alcançá-la. Hoje lutamos por defendê-la e consolidá-la. O Partido Comunista luta para que o novo Portugal que construímos tenha duas características essenciais: Amplas liberdades para todos os cidadãos e profundas transformações económicas e sociais abrindo caminho ao socialismo. No tempo do fascismo o Partido Comunista lutou nas mais difíceis condições pelas liberdades e pelos direitos democráticos fundamentais: a liberdade de expressão do pensamento, a liberdade de Imprensa, a liberdade da formação e actividade de partidos políticos, a liberdade de reunião e de manifestação, a liberdade da formação de sindicatos pelos trabalhadores, o direito à greve. No tempo do fascismo ninguém mais do que os comunistas lutou pelas liberdades e direitos dos cidadãos."

Como se pode verificar de seguida, ocorre a construção de um discurso invocando, de novo, a atuação divisionista do PS para, em contraponto, veicular a imagem de um PCP conciliador e coeso em torno dos interesses do povo português: 
“actualmente fala-se muito de querelas de partidos. Esta expressão é inexacta e deforma a realidade. A questão é outra. A querela não é entre partidos. É sim entre partidos que se colocam contra o processo revolucionário e as forças (partidos ou não) que estão pelo processo revolucionário. Entre estas últimas forças conta-se o PCP e por isso é um dos alvos principais dos ataques reaccionários, conservadores e oportunistas. Que fazer nesta situação? (...) a direcção do Partido Socialista continua a sua campanha anticomunista, (...) por esse facto vamos nós (...) incitar por sua vez os trabalhadores a fazer uma guerra santa contra os socialistas? (...) nós não seguimos nem seguiremos uma tal política. (...) Os nossos inimigos principais são a reacção, são os grandes capitalistas, são os grandes agrários (...) nesse combate, estamos sempre dispostos a unirmo-nos fraternalmente (...) pequeno proprietário comunista e socialista, mesmos interesses, mesmas dificuldades, mesmos inimigos. Podem e devem unir-se na luta (...) Nós, os comunistas, não vamos estar à espera que outros partidos da coligação governamental cessem actividades divisionistas e anticomunistas (...) Nós os comunistas não somos animados por um cego sectarismo, nem por ambições pessoais ou de grupo (...) Defendemos acima de tudo os interesses do povo português."

\section{9/6/75 - Duas Concepções de Jornalismo}

É dada uma imagem da imprensa soviética como solidária não só com o processo revolucionário, mas também com o período de luta que o país travou contra a ditadura, face a uma imprensa internacional que é descrita como "capitalista" e "burguesa", que no tempo da ditadura não contestou esse regime e vem agora defender uma liberdade e democracia "talhada para a defesa de interesses alheios ao povo":
“A imprensa dos países socialistas, em particular a imprensa soviética tem-se distinguido pela objectividade e seriedade com que se tem referido à evolução da situação política no nosso país. Mostraram coerência ao defenderem a batalha empreendida contra o regime fascista, mesmo antes do 25 de Abril, não como a imprensa do mundo capitalista que das raras vezes que se referia ao nosso país falava de estabilidade e segurança (possivelmente a referir-se àquela sentida pelas multinacionais aqui instaladas) (...) A imprensa burguesa é pródiga nos insultos e insinuações contra o processo revolucionário no nosso país. Revela uma sensibilidade incomparavelmente mais acentuada para com a sorte de uma liberdade e de uma democracia talhada para a defesa dos interesses alheios aos do povo português (...) bem nossas conhecidas e que sem dúvida alguma (nisso podemos considerar-nos de acordo) sofrem um perigo de morte no nosso país. Preferimos a liberdade e a democracia para o povo português."

\section{6/6/75 - O Plano de Acção Política do MFA e o Processo Revolucionário}

Neste artigo a construção do discurso faz-se invocando a atuação do partido em confronto e luta, para justificar uma mudança de posição relativa à prática do pluralismo, conceito consensualmente defendido como estratégia de atuação no pós-revolução. Desta forma viabilizam um conteúdo polémico, a de que o pluralismo já não serve os interesses dos portugueses, enquanto ocorrerem atuações divisionistas e reacionárias:

“O PCP sempre defendeu (...) que estava disposto a cooperar com todos os partidos democráticos, verdadeiramente interessados no processo revolucionário (...) A política irracional de alguns partidos da coligação está quase a comprometer a via pluralista para o socialismo (...) Apesar desses ataques e calúnias (...) o PCP considera ainda possível a cooperação entre os partidos. (...) É a actuação objectivamente antiunitária de alguns partidos que está, de facto, a comprometer a via pluripartidarista para o socialismo." 
Nesta sequência, o caso "República" constrói-se no discurso como manobra divisionista em contraponto ao pluralismo socialista. O PCP defende o pluralismo, outrem, comprometem-no com manobras antiunitárias:

“A forma como o caso República está a ser utilizado (...) não serve de forma alguma a causa do pluralismo socialista. É uma coisa por demais sabida que o caso República se insere na luta dos trabalhadores pela liberdade de informação e que o PCP não tem a mínima interferência no conflito (...) É uma calúnia a acusação de assalto aos meios de informação. Agora a publicação de um documento falso como emanado do Partido Comunista da União Soviética com ordens para açaimar a imprensa não comunista é mais uma obstaculização à viabilidade prática do pluralismo socialista."

Neste discurso há uma tentativa por um lado de legitimar a atuação dos trabalhadores em nome da liberdade de imprensa e de se demarcar do conflito - veiculando a mensagem de que esta é uma manobra do PS que juntamente com a publicação de um documento alegadamente falso reforça a inviabilidade "prática do pluralismo socialista".

\section{6/6/75 - Folhetim da República para Francês Ler}

O estilo irónico, em jeito de novela policial, com que é relatada a atuação da equipa do República, ao publicar um documento alegadamente falso que implica o PCP, parece vir reforçar, de novo mais uma vez, o argumento da conspiração das forças reacionárias: Não seria suposto um jornal, com o passado de resistência como o República, a fazer campanha contra uma força política revolucionária. Isto só existe porque o PS retratado na equipa do República se tornou reacionário. A visão supostamente pluralista e democrática do República traduz-se numa visão anti comunista, o que é o mesmo que dizer anti democrática e anti socialista (reacionária):

“Um diário que se diz independente mas na realidade é de direita, reaccionário - 'Le Quotidien de Paris’ - publicou um suplemento de 4 páginas da República. Linguagem, estilo e linha política igualzinha ao Jornal do Caso República. Documento secreto de cinco pontos que deliciou os apreciadores de novelas. $\mathrm{O}$ documento, como é tradicional nesses romances, foi elaborado em Moscovo em gabinetes secretíssimos. A República divulga-o porque caiu nas mãos de jornalistas europeus, devido a uma fuga de informações. É a iniciativas patrióticas, voltadas para a heróica defesa da democracia e do socialismo, contra as ditaduras e especialmente contra o comunismo que a equipa de jornalistas democráticos dirigida pelo dr. Raul Rego se entrega alegremente nestas semanas de descanso. Na visão pluralista e democrática da República os comunistas são já olhados como inimigos (...) Até onde irá a equipa da República na sua escalada antidemocrática e anti-socialista?”

\section{3/7/75 - Álvaro Cunhal no Campo Pequeno}

O discurso inicia com uma invocação de valores a defender pela causa revolucionária:

“às pessoas que se interrogam é necessário dizer que as forças da democracia e do socialismo (...) estão em condições de cortar o passo à reacção e encaminhar Portugal para os elevados objectivos da revolução portuguesa: liberdade, democracia, independência, paz e socialismo".

Feita esta clarificação dos objetivos das "forças democráticas" e dos valores do Partido, o mesmo reforça esta posição invocando a atuação das forças reacionárias (tal como expresso no trecho noticioso atrás) onde se incluem "certos partidos que gritando que certas liberdades estão ameaçadas efetivamente e na prática as põem em perigo." Faz uma importante articulação entre 
a ameaça às liberdades e a ameaça representada pela "democracia burguesa" e o capitalismo, que se não deseja em Portugal, muito antes pelo contrário:

“em Portugal não haverá uma democracia burguesa de tipo ocidental. As forças reaccionárias deformaram grosseiramente esta afirmação gritando: 'Os comunistas dizem não querer as liberdades'.

As democracias burguesas têm dois traços fundamentais: neles existe liberdades, ainda que muito condicionadas, mas existe também o poder económico e mesmo o poder político dos monopólios (...) Nós os comunistas portugueses queremos as liberdades. O que não queremos são os monopólios e os agrários. E não apenas nós. Todas as forças revolucionárias (...) Se atacam a revolução portuguesa não é porque em Portugal estejam ameaçadas as liberdades, mas porque está ameaçado o capitalismo."

O PCP constrói o discurso invocando factos do seu passado que legitimam uma imagem deste Partido enquanto defensor de liberdades, face a um conjunto de forças reacionárias cujo interesse é lutar para defender o que realmente está ameaçado, o capitalismo (como denota o extrato anterior). Desta forma legitima a atuação dos trabalhadores do República, embora no seu discurso se procure demarcar do conflito:

"O PCP, como sempre tem insistido, luta por um regime em que existam as mais amplas liberdades incluindo a liberdade de imprensa, a liberdade de formação e actividade dos partidos políticos, a liberdade religiosa. Não se trata de declarações formais. Factos -28 Setembro, 11 de Março, PCP à frente da classe operária e das massas populares em cooperação com outras formações progressistas e em estreita aliança com o MFA fez frente à ofensiva reaccionária e mostrou de cada vez a sua dedicação na luta em defesa das liberdades (...) Certas forças políticas portuguesas e a reacção internacional fazem grande alarido em torno do caso República querendo mostrar que ele significa precisamente a liquidação das liberdades. No quadro da revolução portuguesa a luta dos trabalhadores da República não só tem na sua base um conflito de trabalho, como se insere na luta dos trabalhadores portugueses, não contra a liberdade mas precisamente pela liberdade de imprensa. Foram fundamentalmente as lutas dos trabalhadores que levaram à liquidação do controle dos grandes órgãos de informação pelos grupos monopolistas e à conquista do direito a uma informação livre. O PCP não teve qualquer intervenção na luta dos trabalhadores do República como o PS tão bem sabe, apesar de que espalha pelo mundo que o caso República é uma tentativa do PCP para apossar do que falsamente dizem ser o último órgão livre da imprensa portuguesa! O PCP considera que a luta dos trabalhadores poderia em alguns aspectos ter sido mais bem orientada (...) Se não fosse a especulação que o PS fez, já há muito o caso República estaria resolvido. Por isso pode perguntar-se porque tem a administração da República criado tantas dificuldades à resolução do problema? Para gritar que as liberdades estão ameaçadas?"

\section{0/7/75 - Combater o Anticomunismo é lutar pela Revolução!}

A argumentação constrói-se, de novo, com base na tese da conspiração - o "Anticomunismo":

“Cabe tudo nele: a reacção tradicional, a ultra-esquerda pseudo revolucionária e a legião confusa de adeptos da social democracia. Não estão de acordo entre si (...) Um pólo de convergência congrega os elementos que constituem essa estranhíssima aliança (...) - o anticomunismo!"

É feito um reforço desse argumento conspirativo invocando factos recentes que puseram em causa a atuação do PCP, nos quais se inclui o caso "República": 
"Tudo lhes serve para fabricarem o anticomunismo. O $1^{\circ}$ de Maio, a unicidade sindical, a ocupação de uma Rádio, o conflito interno do 'República' (...) A propósito do caso 'República' foi desencadeada contra o nosso Partido uma intensa campanha de calúnias. Fomos gratuitamente responsabilizados por um conflito ao qual éramos completamente estranhos. Mas nas ruas, em manifestações de carácter contra-revolucionário, o alvo das críticas da reacção e dos grupelhos verbalistas de uma ultra-esquerda delirante, fomos novamente nós, comunistas."

\section{Portugal Socialista - (13 notícias analisadas)}

\section{1/05/75 - Miséria das Interrogações}

A notícia em questão inicia-se com a seguinte declaração: "Conhecendo nós a ânsia mobilizadora do PC no sentido da total ocupação dos meios de informação..."

O contexto argumentativo inclui, como contraponto, uma crítica feita por Eduardo Prado Coelho, (in "A Capital", 12 de Maio de 1975), acusado de "porta-voz" do PCP nas considerações que tece sobre o PS: "se o curso da revolução portuguesa tomar aspectos negativos sejam eles quais forem, não deixaremos de considerar os dirigentes do PS como os principais responsáveis dessa evolução". O jornalista do "Portugal Socialista" faz uma articulação com este discurso de Eduardo Prado Coelho ao qual se contrapõe: assim, à afirmação de Eduardo Prado Coelho que remete para uma responsabilização abstrata e futura do PS face aos "aspectos negativos, sejam eles quais forem", o jornalista do "Portugal Socialista" contrapõe com uma descrição de vários aspetos negativos já presentes na sociedade portuguesa, pelos quais responsabiliza o PCP, nomeadamente o que define como "monolitismo, falta de imaginação, paternalismo vigilante do PC, incapacidade de transformar a sociedade portuguesa numa sociedade livre, a sua impotência em descobrir meios de organização social sem recorrer à repressão".

Denuncia a estratégia de bipolarização de Eduardo Prado Coelho em termos de "revolução ou reação" e "fascismo ou via progressista". O citado jornalista de "Portugal Socialista" descreve-a da seguinte forma:

“Estas manobras simplórias apresentam uma dupla velhacaria: nunca demonstram carácter necessário de bipolarização; nunca explicitam o subentendido que transportam, subentendido que pretende inculcar nos espíritos a ideia de que 'só' o PC é 'via progressista'."

\section{1/05/75 - Uma informação independente, objectiva e não partidária}

Há uma acusação de falta de independência de três jornais diários, acusados de serem veículos de propaganda do PCP. Neste sentido procura-se reforçar a acusação de que alguns meios de comunicação social, pelo controlo que o PCP tem sobre eles, não exercem, enquanto órgãos de informação financiados pelo Estado, a qualidade de serviço público a que estão obrigados:

"O Partido Socialista tem, até agora, dado provas da maior paciência relativamente à utilização dos financiamentos estaduais aos jornais 'O Século', 'Diário de Notícias e Diário de Lisboa' (...) Acontece, porém, que o Partido Socialista não pode ignorar a forma como são despendidos os dinheiros públicos entregues aos citados órgãos de informação."

Incentiva, pois, à indignação dos leitores ao referir financiamentos públicos . Denuncia aqueles órgãos de informação, financiados "com dinheiros públicos", manterem "a propaganda quotidiana de um partido que representa 13 por cento do povo português" e de serem "veículos ideológicos da propaganda do PCP, como o confirma a sistemática campanha anti-socialista por eles desencadeados". 
Contrapõe-se, pois, a tal "propaganda" e manipulação partidária, a reivindicação da independência e objetividade: "O Partido Socialista exige, portanto, que todos os Órgãos de Comunicação Social financiados pelo Estado assegurem informação independente, objetiva e nãopartidária”, surgindo assim o PS como arauto de tal Independência e Objetividade na área da Comunicação Social

\section{1/05/75 - Um Atentado à Liberdade de Informação}

O artigo refere-se aos acontecimentos em torno de "O República", e associa a luta pela liberdade de informação da redação da "República" à luta do Povo Português pela democracia e pelo socialismo:
"A indignação que se sentia durante a tarde de segunda-feira, à medida que o povo de Lisboa tomava consciência da escalada contra a liberdade de Imprensa que se estava a verificar na 'República', manifestou-se claramente toda a noite (...) A consciência de que a luta pela liberdade de Informação da redacção da 'República' está ligada à luta do Povo Português pela democracia e pelo socialismo, fez com que nada demovesse os manifestantes”.

Associa um argumento consensual - luta do Povo pela democracia - a um argumento novo luta da redação pela liberdade de informação. É invocado o discurso da liberdade de imprensa num contexto democrático para legitimar a mobilização - há uma generalização dos argumentos em causa.

Recorre-se a mecanismo retórico de extremização dos factos: "Nem a presença de destacamentos de forças militares e militarizadas, nem a chuva que caía, nem a presença de militares e de 'chaimites' modificaram a determinação dos populares”.

\section{1/05/75 - O Caso República em comunicados}

Veicula mensagem de jornalistas "impedidos de livremente exercer a sua actividade" e de "uma comissão de trabalhadores que ultrapassando os poderes para que foi constituída (dialogar com a direcção e a administração)" procura promover "a demissão da direcção e da chefia da redacção" - há, pois, um enfoque no binómio Liberdade ameaçada vs. usurpação do poder por parte dos trabalhadores.

São realçadas as credenciais de Raul Rego, "incontestável figura do resistente e lutador antifascista que acaba de ser eleito à Assembleia Constituinte e a quem o 25 de Abril tanto deve".

Há um apelo ao apoio dos populares incitando-os a manifestarem-se à porta do jornal, em nome da "liberdade de expressão": "Só os seus leitores, que tantas provas têm dado da sua solidariedade connosco, nos poderão ajudar, por forma a restituir à 'República', a liberdade de expressão que tão arduamente conquistou". Assiste-se à construção do argumento com vista a predispor para a audiência à ação, tendo por base um símbolo da "Liberdade de Expressão" tão "arduamente" conquistada.

\section{1/05/75 - Socialistas sim, cães-policias, não!}

Reação a uma referida declaração de Cunhal de 19/5/75 (“O Século”): “direcção socialista atiça os seus militantes contra o PCP”.

O jornalista subentende nesta mensagem uma acusação ofensiva por parte de Cunhal. Segundo o mesmo jornalista: "Perante esta firmação, declaramos que nós, militantes do PS, não somos atiçados por ninguém, porque somos seres humanos e não cães adestrados pelo dono" que seguem as ordens do partido sem questionar.

O jornalista na sua resposta utiliza aqui os mecanismos retóricos da Inoculação e da Confissão: 
"Nós militantes do PS, podemos não começámos a hostilizar o PCP, foi o PCP que nos hostilizou, na sua ânsia totalitária de amordaçar a Nação. Nós, militantes do PS, podemos provar que por diversas vezes nos insurgimos contra o 'Anticomunismo', tempo em que a palavra 'Comunismo' era usada para amedrontar o Povo português. Nós, militantes do PS, só podemos ser acusados de não aceitar o despotismo de Cunhal’.

\section{3/05/75 - O Partido Socialista perante o povo português - Conferência de Imprensa}

Mário Soares é citado nesta conferência de imprensa, declarando: “[...] o caso da 'República' simboliza para nós o problema da liberdade de informação e implicitamente da liberdade em Portugal."

É feito o enquadramento justificativo da realização da conferência: análise do MFA aos acontecimentos do $1^{\circ}$ Maio - realce do facto do PS não ter sido consultado nessa análise; atividades do partido socialista e sua integração no processo revolucionário; o Caso "República" como atentado à "liberdade de informação".

Há um enfoque da responsabilidade do PS para com o povo português que o elegeu como partido maioritário à assembleia Constituinte:

"Como é sabido, houve dois milhões e trezentos mil portugueses que votaram no Partido Socialista e confiaram nele". Soares destaca o facto de após os resultados favoráveis ao partido, mesmo assim não ter levantado o problema da modificação do elenco governamental: “Como sabem (...) nós não pusemos o problema da modificação do elenco governamental, e não pusemos porque nós temos por hábito honrar os nossos compromissos.

Há um Pacto que assinámos com o MFA, e ao qual somos fiéis".

Com este argumento procura reforçar a imagem PS de digna de confiança, fiel aos seus compromissos, em "oposição" ao PCP, cujas atitudes que "desvirtuam" práticas democráticas: "naturalmente não podíamos admitir que (depois do Povo português se ter pronunciado de maneira tão expressiva e eloquente) a Imprensa e os outros meios de Comunicação Social continuassem a ser manipulados ao serviço de um só partido"

Soares coloca o problema da questão do Caso "República" como central no panorama político:

"relativamente a uma questão fundamental, que é a questão concernente aos órgãos da Informação - o pluralismo não está a ser respeitado - isso, para nós, é uma questão vital, sendo o caso 'República' apenas uma ilustração do referido problema na nível dos meios de comunicação".

Refere a campanha anti-socialista com "insinuações caluniosas (...) acerca do pseudo e falso empenhamento dos dirigentes do Partido Socialista no 11 de Março" e às críticas à democracia por parte do PCP: "as críticas que se fazem às eleições (...) como expressão da maioria silenciosa. São ainda as críticas que se fazem à democracia europeia, para se acabar nas críticas à democracia pura e simplesmente". Desta forma procura aclarar os argumentos utilizados pelo PCP relativo à forma de Democracia preferida pelo partido socialista e seus aliados. Procura desconstruir o argumento "não comunista, logo reaccionário", promovido, no seu entender, pelo PCP, recorrendo ao cenário de antes do 25 de Abril de 1974 em "quem não era fascista era comunista e ia para a cadeia" e referindo, em seguida, "caminhar perigosamente para situação inversa: quem não é comunista (...) é reaccionário ou inimigo do processo revolucionário!”.

Relativamente à natureza do socialismo que o PS pretende ("Que socialismo pretendemos para o nosso país?"), reforça a fidelidade ao pacto com o MFA e defende um socialismo pluralista para Portugal: "o socialismo para o qual caminhamos é um socialismo que respeita as liberdades, é um socialismo pluralista” Mas o mesmo socialismo não está desligado da democracia representativa: 
“Ora nós entendemos que se o Povo Português se exprimiu nas eleições (...) a favor claramente, pela opção socialista (...) também se exprimiu, de uma maneira igualmente clara, a favor de um certo tipo de socialismo e esse socialismo é o socialismo que respeita o pluralismo e as liberdades. O povo Português não quer (...) não aceita (...) uma ditadura comunista em Portugal ou uma democracia tipo democracia popular".

\section{3/05/75 - Carta ao Conselho de Revolução}

Carta de Manuel alegre em resposta a uma descrição dita tendenciosa do Diário de Notícias em relação aos acontecimentos de 19 Maio (manifestação frente às instalações do jornal "República"), que, no entender de Alegre teve o objetivo de criar divisões entre o MFA.

A função desta notícia parece ser a de demonstrar e reforçar o facto de a imprensa portuguesa estar a ser controlada e a manipular o povo, bem como de novo colocar em evidência uma campanha anti-socialista (argumento Conspirativo):

"O relato publicado (...) é um exemplo flagrante de manipulação da opinião pública, comparável à que neste país existiu durante 48 anos (...) Há nesse relato intenção deliberada de deturpar a verdade, com o objectivo de criar divisões entre o MFA e o Partido Socialista (...) $\mathrm{O}$ relato (...) manifestamente tendencioso, revelador de um espirito sectário e antisocialista, caracteriza atualmente quase todos os órgãos de informação (...) Não deixa de ser curioso que militantes e resistentes antifascistas, socialistas por convicção (...) continuem a ser caluniados pelos mesmos órgãos que os caluniavam antes do 25 de Abril (...) os militantes do Partido Socialista já não têm, praticamente, acesso à imprensa".

23/05/75 - Se cedêssemos a Liberdade de Expressão estaria definitivamente ameaçada no nosso País - Disseram os Jornalistas em Conferência de Imprensa

O Caso "República" é visto pelos jornalistas (jornalistas de "O República"), nesta Conferência de Imprensa como um conflito político: "A situação de conflito político verificada na 'República' (...) resulta de uma acção de um grupo de trabalhadores no sentido de controlar o jornal, não apenas administrativamente, mas também na sua orientação e conteúdo". O acontecimento é descrito como uma usurpação de poder ilegítima por uma pseudominoria:

"Esse grupo pretendeu criar uma situação de facto, a partir de uma pseudominoria. E digo pseudo porque temos elementos que nos permitem afirmar que houve trabalhadores que assinaram um papel em branco, depois de lhes dizerem que as assinaturas se destinavam a um fim completamente diferente" - procura-se, assim descredibilizar este grupo descrevendo a forma como conseguiram obter assinaturas".

Identificam-se os jornalistas como defensores da liberdade de expressão e do direito à Informação, com recurso nomeadamente ao mecanismo de apresentação de credenciais na luta antifascista e pela liberdade de informação: "António Marcelino Mesquita, o mais velho redactor da 'República' e prisioneiro durante 14 anos no Tarrafal faz então um breve historial da vida da 'República' (...) A nossa luta principal deve ser pela liberdade de expressão e pelo direito à Informação"

\section{3/05/75 - Manter a democracia em Portugal}

Conflito ideológico é o que destaca o jornalista desta notícia, a propósito das palavras do então Ministro da Comunicação Social sobre o Caso República: "Conflito ideológico, eis como o ministro (...) com clareza classificou o "Caso república"'. Isto para defender que este caso concerne à democracia pluralista - "Os democratas empenham-se na luta pelo pluralismo na Informação" - que ultrapassa o foro das lutas partidárias: "Deslocar o 'Caso República' unicamente para o campo das lutas partidárias é profundamente errado (...) primordialmente é um caso de todo o 
Povo Português"; num discurso para mobilizar para a causa, não são só os socialistas, mas todos os portugueses democratas.

O jornalista usa os mecanismos de Inoculação e de Recurso à Apresentação de Credenciais para deslegitimar o PCP, aqui abertamente evocado:

“quando (...) pretendem o saneamento do lutador antifascista Raul Rego, estão objectivamente (...) a defender as forças antissocialistas (...) o PCP (...) sabemos que tem feito tudo para decapitar o Partido Socialista".

O mecanismo da extremização é usado ao comparar a defesa pela independência do "República" com a "defesa do processo revolucionário em que os socialistas estão particularmente empenhados, (e) a defesa da independência nacional".

\section{9/05/75 - A luta pela informação}

A ‘Luta pela Informação’ é o título da referida notícia sobre um Comício “promovido pelos profissionais da informação do Partido Socialista"

Apesar do uso do mecanismo da Confissão - " A luta pela informação objectiva e crítica do povo português mobilizou milhares de socialistas" - há também uma retórica, com recurso aos mecanismos de apresentação de credenciais e inoculação, com apelo a uma luta que se pretende não ser só do PS: "fala-vos um jornalista sem filiação partidária, que se orgulha de um passado de luta pelo direito à Informação." O reforço da imparcialidade e apartidarismo, com recurso ao mecanismo de descrição de argumentos com dados factuais, é recorrente na notícia: "De sublinhar (a presença no comício de) dois profissionais competentes e corajosos, já no tempo do fascismo, e sem filiação partidária, terem usado da palavra nesta luta comum a todos os profissionais da informação verdadeiramente progressistas". Esta frase denota igualmente a generalização do problema apontado para uma esfera além dos partidos e que diz respeito a toda a classe jornalística.

Os mecanismos de inoculação e apresentação de credenciais são usados de forma recorrente: “Quando Raul Rego (...) me convidou para assumir a Direcção do 'Diário de Notícias', eu entendi que o convite não era ao socialista, mas ao antifascista que sempre fui”.

“nós, jornalistas, dissemos-lhes (...) que não se saneia um homem como Raul Rego (...) que foi três vezes preso pela PIDE. Não se saneia um homem que foi esbofeteado pela PIDE (...) não se saneia um homem cujos actos foram sempre coerentes com os actos de um grande lutador antifascista".

A referência, de novo, à falta de independência de outros órgãos de informação nacionalizados, é repetida:

"o dinheiro começa a sair dos cofres da fazenda (...) pergunto se o povo tem que pagar pela propaganda de um partido (...) para termos uma informação deste género o melhor é acabar com os jornais, criar uma Informação única (...) é fácil, basta fazer como se fez com a legalização da Intersindical”.

A anterior acusação de que se trata de um conflito político é reiterada: “ $\mathrm{O}$ caso ‘República’ não é um conflito de trabalho (...) O problema da 'República' é um caso político, é mais uma tomada de assalto a um órgão de informação".

De novo, também, é denunciada uma alegada estratégia do PCP em torno da bipolarização "Revolução vs. Reacção":

"quando não se tem argumentos para convencer os trabalhadores (que efectivamente lutam contra a instauração de uma ditadura neste País) são eles imediatamente chamados de 
reaccionários"; "Não admira pois que a Imprensa (...) seja como o próprio ministro da Comunicação social ressaltou (...) 'pouco crítica' (...) Mas pergunta-se: quantos se atrevem a criticar sob pena de ser apelidado de 'divisionista', 'reaccionário' ou 'contra-revolucionário'?’.

O enfoque sobre o argumento da "falta de Liberdade de expressão" é também de novo repetido, associado por vezes ao argumento Conspirativo, ou com recurso à apresentação de credenciais: “ a liberdade de expressão de pensamento é uma das manifestações da própria liberdade e condição fundamental da democracia"; “Aquilo a que se assiste presentemente na generalidade dos jornais portugueses é a monopolização da informação por determinado partido e seus satélites, o que representa um regresso à Censura"; "Os agentes desta cabala (...) que têm como fim último roubar ao Povo português o direito à Informação que lhe foi restituído em 25 de Abril”; "interesses de minorias, ocultas sob uma capa supostamente revolucionária, pretendem silenciar as vozes livres deste país"; "Será possível (...) que se leve tão longe o assalto à informação? Que se queira calar a voz da 'República' (que resistiu a Salazar e (...) Caetano?)”.

A tónica na legitimidade eleitoral é colocada em relevo por Jaime Gama, num aparente contraponto ao argumento do "eleitoralismo" apresentado pelo PCP:

“como se só houvesse eleições verdadeiramente livres quando acontecesse o impossível, isto é, quando o Partido Comunista tivesse 100 por cento dos votos (...) É à Assembleia Constituinte, é à assembleia eleita pelo Povo Português que cumpre decidir qual é o regime das suas liberdades públicas".

\section{4/6/75 - A atitude do Partido Comunista compromete a segurança da Europa}

A presente notícia relata contactos de Soares com líderes políticos europeus, seja de outros Partidos Socialistas, seja com os Partidos Comunistas Espanhol e Italiano.

A validação das posições do PS por estes dois últimos partidos é clara: “ o dirigente do PCE (Espanhol) mantém muito melhores relações com os socialistas portugueses do que com os partidários de Cunhal. Declarou-nos também que considerava deplorável a suspensão do jornal 'República'; "A simpatia activa dos comunistas espanhóis e também dos comunistas italianos satisfaz naturalmente Mário Soares."

As alegadas "intenções" do PCP, em promover uma alegada "Democracia popular" são patenteadas versus uma "Democracia Política" defendida pelo PS:
“aparentemente (...) eles (PCP) pretendem expulsar-nos do Governo a fim de nele se manterem sós, ou com os militares incitando estes últimos a aceitar uma opção de democracia popular. Trata-se de uma forma não viável em Portugal (...) Nós queremos salvar e manter a democracia política. Álvaro Cunhal diz o contrário. Ele afirma que o eleitoralismo está em contradição com o processo revolucionário. Caminhamos para a democracia popular ou para a democracia política?"

O conflito na "República" é de novo referenciado como um conflito político, que põe em causa o pluralismo no sector da Informação:

"Pedimos que o pluralismo seja assegurado a todos os níveis do aparelho de Estado e, em particular, na Informação (...) Pedimos no que diz respeito ao caso República que a Lei de Imprensa seja aplicada (...) que prevê que o director da publicação seja escolhido pela empresa, de acordo com o Conselho de Redacção. (...) o conflito é político."

A Legitimidade Eleitoral do regime político, e do próprio PS (ganhador das eleições à Constituinte) é relevada: "Acumulam-se graves problemas. Não podemos permanecer no governo de uma maneira teórica."; "Somos o partido mais forte do país e não estamos realmente associados 
às grandes decisões políticas. Não reclamamos de modo algum uma remodelação governamental, mas não podemos aceitar a priori ser vítimas de uma constante discriminação."

\section{4/6/75 - Karl Marx Contra-Revolucionário}

A Liberdade de Imprensa, com uso de uma voz credível (Karl Marx) para veicular o ponto de vista do jornalista (mecanismo retórico de apresentação de credenciais), é a tónica da notícia:

“"Na ausência da liberdade de imprensa, todas as outras liberdades não passam de miragens' (...) À liberdade de imprensa que Marx assim defendia, pretendem os totalitaristas lusomoscovitas contrapor o monolitismo, que educa as massas e as prepara para a gloriosa batalha do comunismo, tal como o pastor encaminha as ovelhas do redil para o aprisco, onde as ordenhará (...) O pluralismo cria ou desenvolve no seu seio a contra-revolução? Citamos ainda Marx: A verdadeira censura, aquela cujas raízes mergulham na própria essência da liberdade de imprensa é a Crítica."

\section{9/7/75 Para reflexão: A Liberdade Revolucionária (artigo de Edgar Morin)}

Um artigo do sociólogo Edgar Morin publicado no jornal "Nouvelle Observateur" é traduzido no "Portugal Socialista" de 9/7/75. O recurso ao mecanismo de "apresentação de credenciais", tendo em conta o estatuto e percurso de esquerda deste intelectual francês, é notório. Morin é citado num contexto em que é realizada a construção do argumento da "liberdade de imprensa" por contraponto ao argumento da clivagem "revolução versus reacção":

"Muitos daqueles para quem a liberdade de imprensa, em relação a um regime fascista ou
reacionário, constitui um bem absoluto e uma exigência progressista, consideram esta mesma
liberdade, quando se inicia um processo considerado revolucionário, como um bem acessório
e um perigo reacionário (...) todo o protesto contra um atentado à liberdade de Imprensa, tal
como toda a defesa da 'República', aparece necessariamente como uma contra-revolucionária".

\section{DISCUSSÃO}

Seguidamente, apresenta-se uma síntese dos principais Mecanismos de Retórica sobre o Caso República, maioritariamente utilizados por cada um dos Partidos:

$P C P$ - Recurso ao mecanismo retórico da minimização relativamente ao "Caso República". Bipolarização da realidade social e política, construindo com essa bipolarização a imagem de um PS divisionista e reacionário, contrapondo a essa imagem a de um PCP unificador das massas, vanguarda da revolução. Há também o recurso ao mecanismo de "distanciamento" face ao caso República, servindo-se desse argumento para invocar clima de violência e perigo na continuidade do processo revolucionário.

Os conteúdos das notícias veiculadas são maioritariamente uma contra argumentação face às acusações por parte do PS. É recorrente nos discursos o binómio "revolução vs. Reação". O recurso ao mecanismo de "apresentação de credenciais" de um Partido que lutou pela liberdade no decurso do fascismo, é também patente.

$P S$ - Recurso ao mecanismo retórico de extremização dos factos O PS intitula-se o Partido defensor da liberdade ameaçada - defendem a liberdade de imprensa e servem-se da retórica para uma extrapolação táctica dessa liberdade para o meio político e social, servindo-se para tal do "Caso República".

Utiliza frequentemente o recurso a credenciais para credibilizar as opiniões. Procura fazer aderir o povo para as suas teses fazendo alusão aos currículos de alguns dos seus militantes ou 
simpatizantes. Não tem a credibilidade do PCP enquanto partido, pelos anos de luta clandestina, procurando por isso utilizar a credibilidade de individualidades militantes e simpatizantes do partido, reforçada pelo passado ativo contra o regime fascista.

Especificamente em relação ao caso "República" vemos aqui uma diferenciação clara nos mecanismos retóricos de Minimização vs. Extremização utilizados por cada um dos Partidos. O PCP nas situações (poucas face ao PS) em que se pronunciou sobre o caso usou de uma forma geral a estratégia da minimização, não se pronunciando tanto sobre o caso em si, mas sim sobre a atitude do PS face aos acontecimentos. Procurou usar a postura do PS para confirmar a sua tese de aliado de uma fação reacionária. O recurso à minimização e ao distanciamento reforça o facto alegado de não envolvimento no caso, e de aproveitamento político do mesmo por parte do PS. O mecanismo da extremização na exposição do caso, por parte do PS, parece ter por objetivo incitar à ação a audiência. O PS procura usar o acontecimento para reforçar o argumento de:

Os discursos veiculados nos dois jornais analisados traduzem a tomada de posição de cada força política, particularizada no caso República e extrapolada pelos dois grupos políticos em confronto, para o contexto de controvérsia político-ideológica do país.

No discurso socialista a tónica dilemática coloca-se entre a defesa da liberdade, conquistada na revolução de Abril, de um pluralismo construído como liberdade de opinião, de representatividade das diversas correntes de pensamento socialista em prol de um socialismo em liberdade, face a uma visão única e limitadora da liberdade de expressão das diversas correntes do pensamento socialista, alegadamente defendida pelo PCP. No quadro abaixo apresentamos as polaridades ideológicas que se realçam no discurso veiculado no "Portugal Socialista":

\section{QUADRO 1}

Polaridades Ideológicas veiculados no "Portugal Socialista"

\begin{tabular}{lll}
\hline Discurso "Portugal Socialista" & PCP & PS \\
\hline & Totalitarismo & Pluralismo \\
& Controlo & Liberdade \\
\hline
\end{tabular}

No discurso comunista a tónica dilemática coloca-se entre ser revolucionário e defender práticas revolucionárias, ou ser reacionário e defender uma liberdade de expressão que basicamente significa a expressão de interesses capitalistas ou burgueses, alheios aos interesses do povo português.

No quadro a seguir apresentamos as polaridades ideológicas veiculadas no "Avante":

\section{QUADRO 2}

Polaridades Ideológicas veiculadas no "Avante"

\begin{tabular}{lll}
\hline Discurso Avante! & PCP & PS \\
\hline & $\begin{array}{l}\text { Vanguarda Revolucionária } \\
\begin{array}{l}\text { Democracia ao serviço dos interesses } \\
\text { do povo, da classe operária }\end{array}\end{array}$ & $\begin{array}{l}\text { Aliado de Forças Reacionárias } \\
\text { Democracia ao serviço dos } \\
\text { interesses burgueses }\end{array}$ \\
\hline
\end{tabular}

Além das funções epistémica e persuasivas, em termos retóricos, estas dicotomias são exploradas por ambos os partidos também para extremar posições e manter coesos os grupos a que pertencem (Bar-Tal, 2000). 
Procura-se, agora, concluir o trabalho através de uma análise dos momentos em que os discursos das duas formações políticas se veiculam como Maioritário vs. Minoritário e fornecer uma possível interpretação com base no pressuposto de Billig $(1991,2012)$ de que defender-se um determinada posição, é sempre uma oposição a uma opinião ou atitude contrária.

O PCP, nos seus discursos, constrói-se maioritário evocando a Aliança Povo-MFA, bem como a legitimidade revolucionária assente no pacto do MFA com os Partidos. Fá-lo em contraponto às ações da reação - o que ressalta pela recorrência ao Argumento Conspirativo ("ameaças contrarevolucionárias") no discurso do PCP - e ao fenómeno do "eleitoralismo", todo um processo que, no entender deste Partido, ocorreu nas eleições à Assembleia Constituinte, associado a um "falso democratismo" da classe burguesa, e inconciliável com o processo revolucionário.

Credibilizado por longos anos de clandestinidade e de "luta pelas liberdades", reconhecidamente a principal oposição ao regime fascista, cria também a ideia de uma força coesa e forte, vanguarda, no processo revolucionário, da classe trabalhadora.

O discurso do PCP, na forma como se "coloca" ao lado de uma "maioria revolucionária", procura, simultaneamente, veicular a imagem de uma minoria reacionária (conspirativa e anticomunista) associada ao Partido Socialista, o qual surge como força "Divisionista" naquele processo, e que é necessário combater, dado que aquela minoria reacionária poderia pôr em causa as liberdades conquistadas com o 25 de Abril.

O discurso do PS constrói-se, por seu lado, maioritário num momento em que se pretende opor, firme e claramente, ao avanço do PCP (no caso, em análise, na suposta tomada de controlo dos Órgãos de Comunicação Social, particularizada no caso "República”). Recorre, este caso, ao argumento da legitimidade eleitoral, fruto dos resultados das eleições à Assembleia Constituinte, alertando para uma possível "ditadura".

Altera para minoritário, quando se refere à falta de influência no governo provisório (na participação nas decisões políticas de tal Governo), para evidenciar o peso que o PCP exerce, apesar dos resultados eleitorais.

Ao contrário do PCP que minimiza o Caso "República" e adota um certo distanciamento, o PS, quando se debruça sobre o caso, convoca o oponente para o discurso. Tal evocação funciona como contraste para a posição do Partido Socialista, servindo, sobretudo, para argumentar contra a escalada "totalitarista" da atuação do PCP.

\section{REFERÊNCIAS}

Avillez, M. J. (1996). Soares. Ditadura e revolução. Lisboa: Público.

Babo-Lança, I. (2006). A configuração dos acontecimentos políticos: O “Caso República” e as Manifestações nos Açores em 1975. Coimbra: Minerva.

Bar-Tal, D. (2000). Sharing beliefs in a society: Social psychological analysis. Thousand Oaks: Age.

Berger, P., \& Luckman, T. (1966/1973). A construção social da realidade. Petrópolis: Vozes.

Billig, M. (1991). Ideology and opinions. Studies in rhetorical psychology. London: Sage.

Billig, M. (2012). Undisciplined beginnings: Academic success and discoursive psycgology. British Journal of Social Psychology, 51,413-424.

Bordieu, P. (1989). O poder simbólico. Lisboa: Difel.

Brito, C. (2010). Álvaro Cunhal: Sete fôlegos do combatente (Memórias). Lisboa: Edições Nelson de Matos. 
Castro, P. (2002). Natureza, ciência e retórica na construção social da ideia de ambiente. Lisboa: Fundação Calouste Gulbenkian / Fundação para a Ciência e Tecnologia.

Dil, F., \& Pina, C. (1975). Operação República: A política de uma crise. Uma análise independente. Lisboa: Edições Terceiro Mundo.

Medeiros Ferreira, J. (1994). Portugal em transe (1974-1985). In J. Mattoso (Direção), História de Portugal (vol. 8). Lisboa: Círculo de Leitores.

Mesquita, M. (2005). O Caso República. Um incidente crítico. Consultado em 29 de Julho de 2009, através de http/webjornal.blogspot.com/2005/05/o-caso-República-um-incidente-critico-um.html

Perelman, Ch. (1997). O império retórico: Retórica e argumentação. Lisboa: ASA.

Perelman, Ch., \& Olbrechts-Tyteca, L. (2006). Tratado de argumentação. Lisboa: Instituto Piaget.

Potter, J. (1996). Representing reality: Discourse, rhetoric and social construction. London: Sage.

Reis, A. (2005). O Partido Socialista na revolução. In V. Canas (Org.), O Partido Socialista e a Democracia. Oeiras: Celta.

Rosas, F. (1994). O Estado Novo (1926-1974). In J. Mattoso (Direção), História de Portugal (vol. 7). Lisboa: Círculo de Leitores.

Van Dijk, T. (2006). Ideology and discourse analysis. Journal of Political Ideologies, 11(2), 115-140.

Varela, R. (2011). A história do PCP na Revolução dos Cravos. Lisboa: Bertrand Editora.

The goal of this study is to understand, through discursive practices conveyed by the official media of two political groups - the Socialist Party (Partido Socialista) and the Portuguese Communist Party (Partido Comunista Português) - the way in which these two political parties have constructed the significance of a critical incident which opposed them - the conflict in the "República" newspaper - in the revolutionary context of the post-25 April, 1974. Based on the idea of a "post-modern proposal" of rhetorical analysis of discourse (Billig, 1991, 2012), as well as on the proposals of Critical Analysis of Discourse of Van Dijk (2006), specially the argumentative dichotomy used by the opposing political forces, we reconstruct the ideological polarities used by the two parties and also interpret the moments in which the political discourses are conveyed as majority $v s$. minority and this way we present an analysis of such discourses based on Billig's assumption $(1991,2012)$ that the defense of a certain position can only be understood as opposition (explicit or implicitly) to a contrary position. In the socialist discourse the case "República" is constructed as a rhetorical argument against the "totalitarianism" of PCP's action, promoting a mobilization which, in a context of electoral legitimacy (Elections for the Constituent Assembly that had just been won by the Socialist Party), convokes Portuguese people to fight for freedom of speech, through the rhetorical generalization of the incident. In the communist discourse, the rhetoric of the conspiracy argument ("alliance" of the Socialist Party and the forces opposed to the revolutionary process) associated with the bipolarization of reality surrounding the case (Reaction vs. Revolution) serves the purpose of legitimating the revolutionary action of the Party in the post-25 April environment (namely having in mind the "People-MFA Alliance", recurrently evoked). The analysis of the discourses, having also in attention the rhetorical mechanisms identified by Potter (1996) and Castro (2002) allows the reconstruction of the significance of the conflict beneath the argumentation presented by the political parties in dispute. The main issues at stake are the ideological differences and positions about the future conduct of the country, around two legitimacies: revolutionary $v s$. electoral.

Key-words: 25 April 1974, Discourse analysis, Rhetoric, Politics. 